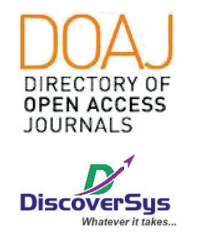

Published by DiscoverSys

\section{Perbandingan profil lipid dengan hipertensi pada diabetes mellitus tipe 2 dengan atau tanpa hipertensi di RS H. Adam Malik, Medan, Indonesia}

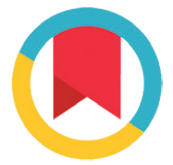

CrossMark

Jelita Siregar*

\section{ABSTRACT}

Background: Atherosclerosis is a complex process. It involve many pathological event including endotelial dysfunction, abnormal lipid metabolism, trombosit activation, trombosis, oxidative stres, activation smooth muscle in blood vessel. Recently, it is known that inflamation plays a role in every steps of atherosklerosis formation. Diabetes Mellitus (DM) is the main risk factor of cardiovascular disease. The epidemiology showed that cardiovasculer mortality 2 to 3 times higher compared to population without DM. This study aims to know the difference in lipid profile between type 2 diabetics' patients with and without hypertension. Method: This is a cross sectional study, which was held in Patology Clinic Department FK-USU / H. Adam Malik Hospital, from Agustus
2017 to November 2017. Target population is type-2 DM. Data were analyzed using SPSS version 17 for windows.

Result: It found 72 subject is 36 people as patient DM type 2 with hypertension and 36 people as control. According to statistic analysis found significant difference between total cholesterol, triglyceride, HDL and LDL in patients with DM type 2 and hypertension compared with patients with DM type 2 without hypertension $(p<0,05)$.

Conclusion: In this study we found there are significant positive increased level of total cholesterol, trigliseride, HDL and LDL and hypertension on type-2 DM population.

Keywords: Diabetes mellitus, hipertension, cholesterol, low density lipoprotein, trigliserida.

Cite This Article: Siregar, J. 2019. Perbandingan profil lipid dengan hipertensi pada diabetes mellitus tipe 2 dengan atau tanpa hipertensi di RS H. Adam Malik, Medan, Indonesia. Intisari Sains Medis 10(2): 354-358. D0I: 10.15562/ism.v10i2.376

\title{
ABSTRAK
}

Latar Belakang: Aterosklerosis merupakan proses yang bersifat kompleks. Proses pembentukannya melibatkan disfungsi endotel, gangguan lipid, aktivasi trombosit, trombosis, stres oksidatif, aktivasi otot polos pembuluh darah dan akhir-akhir ini juga diketahui secara luas adanya peranan inflamasi pada setiap tahapan terbentuknya aterosklerosis. Diabetes Mellitus (DM) merupakan faktor risiko utama penyakit kardiovaskuler, dengan bukti epidemiologi menunjukkan bahwa mortalitas kardiovaskuler 2 hingga 3 kali lebih tinggi dibanding populasi non-DM. Penelitian ini bertujuan untuk mengetahui perbedaan profil lipid pada penderita DM tipe 2 dengan hipertensi dan normotensi.

Metode: Penelitian dilakukan secara cross sectional. Penelitian dilakukan di Departemen Patologi Klinik FK-USU/ RS HAM bekerja sama dengan Departemen Ilmu Penyakit Dalam FK-USU/ RS HAM Medan. Penelitian dimulai pada bulan Agustus 2017 sampai dengan bulan November 2017. Populasi target penelitian adalah penderita DM tipe 2. Data dianalisis menggunakan SPSS versi 17 untuk Windows.

Hasil: Berdasarkan kriteria inklusi dan eksklusi dan perkiraan besar sampel, diperoleh 72 orang sampel yaitu 36 orang pasien DM tipe 2 dengan hipertensi dan 36 orang DM tipe 2 non hipertensi (kontrol). Ditemukan perbedaan yang bermakna antara kadar kolesterol total, trigliserida, HDL dan LDL pada penderita DM tipe 2 dengan hipertensi dibandingkan dengan kelompok DM tipe 2 non hipertensi ( $p<0,05$ ). Simpulan: Pada penelitian ini ditemukan hubungan yang positif antara meningkatnya kadar kolesterol total, trigliserida, HDL dan LDL dengan hipertensi pada populasi DM tipe 2 secara bermakna.
Departemen Patologi Klinik, Fakultas Kedokteran Universitas Sumatera Utara, Medan, Indonesia

*Korespondensi: Jelita Siregar, Departemen Patologi Klinik Fakultas Kedokteran Universitas Sumatera Utara, Medan, Indonesia, jelitasiregar1978@gmail.com

Diterima: $16-11-2018$

Disetujui: 13-05-2019

Diterbitkan: 01-08-2019
Kata Kunci : Diabetes mellitus, hipertensi, kolesterol, low density lipoprotein, trigliserida.

Cite Pasal Ini: Siregar, J. 2019. Perbandingan profil lipid dengan hipertensi pada diabetes mellitus tipe 2 dengan atau tanpa hipertensi di RS H. Adam Malik, Medan, Indonesia. Intisari Sains Medis 10(2): 354-358. D0I: 10.15562/ism.v10i2.376

\section{PENDAHULUAN}

Aterosklerosis merupakan penyebab kematian pada pria dan wanita di Amerika Serikat dan negara-negara maju lainnya. Lipoprotein plasma tertentu memainkan peranan penting dalam aterogenesis terutama yang mengandung apolipoprotein (apo) B 100 telah diidentifikasi sebagai komponen yang mentranspor kolesterol ke dalam dinding arteri. Lipoprotein yang terlibat dalam proses tersebut diantaranya lipoprotein berdensitas rendah (LDL), berdensitas menengah 
(IDL), berdensitas sangat rendah (VLDL) dan lipoprotein $\operatorname{Lp}(\mathrm{a}){ }^{1}$

Diabetes Mellitus (DM) merupakan faktor risiko utama penyakit kardiovaskuler, dengan bukti epidemiologi menunjukkan bahwa mortalitas kardiovaskuler dua hingga tiga kali lebih tinggi dibanding populasi non-DM. Hipertensi sering dijumpai pada penderita DM. Penderita diabetes dengan hipertensi lebih sering menderita penyakit kardiovaskuler dibanding diabetes dengan normotensi. Pada studi epidemiologi dilaporkan mortalitas kardiovaskuler dua hingga tiga kali relative lebih tinggi pada penderita diabetes dengan hipertensi dibanding diabetes normotensi. ${ }^{2,3,4}$ Salah satu faktor yang berpengaruh terhadap terjadinya hipertensi adalah meningkatnya kadar kolesterol LDL pada penderita DM tipe 2. ${ }^{5}$ Studi Framingham melaporkan bahwa LDL kolesterol merupakan suatu komponen aterogenik yang mempunyai dampak klinis signifikan pada perkembangan penyakit kardiovaskuler. The Strong Heart Study, menunjukkan bahwa LDL kolesterol merupakan prediktor independen terhadap kejadian kardiovaskuler pada populasi DM tipe $2.5,6$

Berkaitan dengan latar belakang yang disebutkan di atas, maka penulis ingin mengetahui tentang hubungan profil lipid, dimana khususnya pada LDL, dengan hipertensi pada pasien dengan DM tipe 2.

\section{METODE}

Penelitian ini dilakukan dengan desain potong lintang (cross sectional) bentuk observasi (non eksperimental). Penelitian dilakukan di Departemen Patologi Klinik FK-USU/RSUP H. Adam Malik Medan bekerja sama dengan Departemen Ilmu Penyakit Dalam FK-USU/RSUP H. Adam Malik Medan.

Sampel penelitian seleksi berdasarkan kriteria inklusi dan eksklusi. Kriteria inklusi pada penelitian ini diantaranya penderita DM tipe 2 , menderita hipertensi, usia lebih dari 40 tahun dan bersedia mengikuti penelitian. Penderita diabetes mellitus tipe 2 ditegakan jika memenuhi kriteri ADA 2002 yaitu menunjukan gejala Klinis diabetes dan adanya abnormalitas kadar gula darah pada pemeriksaan laboratorium (Gula darah puasa : > $126 \mathrm{mg} / \mathrm{dl}$ atau gula darah 2 jam post-prandial $>200 \mathrm{mg} / \mathrm{dl}$ ). Kriteri ekslusi diantaranya penderita DM tipe 1, hiperglikemia sekunder seperti akibat pemakaian obat kortikosteroid, gagal ginjal, tidak bersedia mengikuti penelitian. Kontrol adalah pasien yang memenuhi kriteria inklusi dan eksklusi, tetapi tidak sedang menderita hipertensi.

Sampel darah diambil dari vena mediana cubiti. Sebelum pengambilan darah, pasien dipuasakan
10-12 jam. Tempat punksi vena terlebih dahulu dilakukan tindakan aseptik dengan alkohol $70 \%$ dan dibiarkan kering, kemudian dilakukan punksi. Pengambilan darah dilakukan tanpa stasis yang berlebihan dengan disposable syringe $5 \mathrm{cc}$. Darah diambil 5 cc tanpa antikoagulan untuk pemeriksaan kadar LDL Kolesterol dan kadar creatinin darah.

Darah tanpa antikoagulan dibiarkan dalam suhu ruangan selama 30 menit, kemudian disentrifus dengan kecepatan $3000 \mathrm{~g}$ selama 15 menit, serum dipisahkan secara hati-hati ke dalam 2 tabung plastik. Tabung plastik pertama untuk pemeriksaan creatinin dengan alat Cobas 6000 automatic analyzer. Tabung kedua $( \pm 1 \mathrm{ml})$ segera disimpan dalam refrigerator, dengan suhu $2-8^{\circ} \mathrm{C}$ sampai waktu pemeriksaan profil lipid. Data di analisis menggunakan SPSS versi 17.

\section{HASIL}

Penelitian ini melibatkan 36 pasien DM tipe 2 dengan hipertensi dan 36 orang pasien DM tipe 2 yang non hipertensi (control) yang memenuhi kriteria inklusi dan eksklusi. Pada penelitian ini, kelompok DM tipe 2 dengan hipertensi terdiri dari 13 orang pria $(36,1 \%)$ dan 23 orang wanita $(63,9 \%)$ dengan umur rerata $54,72 \pm 5,86$, sedangkan pada DM tipe 2 non hipertensi terdiri dari 22 orang pria $(36,1 \%)$ dan 14 orang wanita $(63,9 \%)$ dengan umur rerata $52,22 \pm 6,44$. Hasil penelitian tersebut diuraikan dalam tabel 1.

Perempuan yang menderita hipertensi dengan dislipidemia adalah sebanyak 19 orang (57,6\%) lebih tinggi dibandingkan laki-laki yang berjumlah 14 orang $(42,4 \%)$. Dalam hal ini jenis kelamin dijumpai perbedaan bermakna antara laki-laki dan perempuan pada kelompok hipertensi dengan dislipidemia dengan non dislipidemia $(\mathrm{p}<0,05)$.

Berdasarkan kelompok umur, pada kedua kelompok terbanyak pada rentang usia 51 sampai 60 tahun 21(58,3\%), tidak dijumpai perbedaan bermakna pada kelompok DM dengan hipertensi dan non hipertensi $(p>0,05)$.

Gambaran indeks massa tubuh pada kedua kelompok didapati rerata $25,69 \pm 2,87$ pada kelompok DM dengan hipertensi dan rerata 25,19 $\pm 1,99$ pada kelompok non hipertensi. Dalam hal ini tidak dijumpai perbedaan bermakna antara Indeks Massa Tubuh pada kelompok DM dengan hipertensi dan non hipertensi $(p>0,05)$.

Untuk lamanya terdiagnosa DM pada kedua kelompok didapati rerata $1,83 \pm 1,29$ pada kelompok DM dengan hipertensi dan rerata 3,69 $\pm 2,12$ pada kelompok non hipertensi. Dalam hal ini dijumpai perbedaan bermakna antara lamanya terdiagnosa DM pada kelompok DM dengan hipertensi dan non hipertensi $(\mathrm{p}<0,05)$. 
Tabel 1 Karakteristik penderita DM tipe 2

\begin{tabular}{lccc}
\hline Variabel & $\begin{array}{c}\text { Hipertensi } \\
(\mathbf{n = 3 6 )}\end{array}$ & $\begin{array}{c}\text { Non Hipetensi } \\
(\mathbf{n = 3 6 )}\end{array}$ & Nilai $\boldsymbol{p}$ \\
\hline Jenis kelamin $(\mathrm{n}, \%)$ & & & \\
$\quad$ Laki-laki & $13(36,1)$ & $14(38,9)$ & \\
$\quad$ Perempuan & $23(63,9)$ & & \\
Umur (n,\%) & $8(22,2)$ & $15(41,7)$ & 0,185 \\
$\quad \leq 50$ tahun & $21(58,3)$ & $17(47,2)$ & \\
$51-60$ tahun & $7(19,5)$ & $4(11,1)$ & 0,34 \\
$\quad 60$ tahun & $25,69 \pm 2,87$ & $25,19 \pm 1,99$ & 0,0001 \\
IMT (kg/m2) $(\bar{x} \pm S D)$ & $1,83 \pm 1,29$ & $3,69 \pm 2,12$ & 0,0001 \\
Lama DM $(\bar{x} \pm S D)$ & $148,89 \pm 11,89$ & $119,72 \pm 9,41$ & 0,0001 \\
TD Sistole $(\bar{x} \pm S D)$ & $94,17 \pm 7,70$ & $75,28 \pm 6,08$ & 0,581 \\
TD Diastole $(\bar{x} \pm S D)$ & $175,50 \pm 70,95$ & $166,39 \pm 68,38$ & 0,502 \\
KGD Puasa $(\bar{x} \pm S D)$ & $287,78 \pm 114,73$ & $269,92 \pm 109,81$ & 0,103 \\
KGD 2 jam PP( $\bar{x} \pm S D)$ & $90,32 \pm 23,51$ & $102,82 \pm 38,86$ &
\end{tabular}

TD: Tekanan Darah, KGD: Kadar gula darah, LFG: Laju filtrasi glomerulus (GFR)

Tabel 2 Perbandingan Kadar Profil Lipid Pada DM tipe 2 dengan Hipertensi dan non Hipertensi

\begin{tabular}{lccc}
\hline Variabel & $\begin{array}{c}\text { DM dengan Hipertensi } \\
(\bar{x} \pm S D), \mathbf{m g} / \mathbf{d l}\end{array}$ & $\begin{array}{c}\text { DM Non Hipetensi } \\
(\bar{x} \pm S D), \mathbf{m g} / \mathbf{d l}\end{array}$ & Nilai $\boldsymbol{p}$ \\
\hline Kolesterol total & $219,53 \pm 46,13$ & $176,14 \pm 36,69$ & 0,0001 \\
Trigliserida & $193,28 \pm 140,51$ & $149,14 \pm 65,39$ & 0,03 \\
HDL & $38,83 \pm 10,68$ & $32,61 \pm 8,87$ & 0,004 \\
LDL & $151,08 \pm 35,55$ & $113,75 \pm 31,12$ & 0,0001
\end{tabular}

Pada pengukuran tekanan darah sistolik dan diastolik didapati rerata tekanan daran sistolik pada kelompok DM dengan hipertensi adalah $148,89 \pm 11,89$ dan pada kelompok non hipertensi adalah 119,72 $\pm 9,40$. Dijumpai perbedaan bermakna antara tekanan darah sistolik pada kelompok DM dengan hipertensi dan non hipertensi $(\mathrm{p}<0,05)$. Pada pengukuran tekanan darah diastolik pada kelompok DM dengan hipertensi didapati rerata tekanan darah $94,17 \pm 7,70$ dan kelompok non hipertensi didapati rerata tekanan darah $75,28 \pm 6,08$. Dalam hal ini dijumpai dijumpai perbedaan bermakna antara tekanan darah diastolik pada kelompok DM dengan hipertensi dan non hipertensi $(\mathrm{p}<0,05)$.

Pada KGD Puasa pada kedua kelompok didapati rerata $175,50 \pm 70,95$ pada kelompok DM dengan hipertensi dan rerata $166,39 \pm 68,38$ pada kelompok non hipertensi. Dalam hal ini tidak dijumpai perbedaan bermakna antara KGD Puasa pada kelompok DM dengan hipertensi dan non hipertensi $(\mathrm{p}>0,05)$.
Pada KGD 2 jam PP pada kedua kelompok didapati rerata $287,78 \pm 114,73$ pada kelompok DM dengan hipertensi dan rerata $269,92 \pm 109,81$ pada kelompok non hipertensi. Dalam hal ini tidak dijumpai perbedaan bermakna antara KGD 2 jam PP pada kelompok DM dengan hipertensi dan non hipertensi $(\mathrm{p}>0,05)$.

Pada LFG pada kedua kelompok didapati rerata $90,32 \pm 23,51$ pada kelompok DM dengan hipertensi dan rerata $102,82 \pm 38,86$ pada kelompok non hipertensi. Dalam hal ini tidak dijumpai perbedaan bermakna antara LFG pada kelompok DM dengan hipertensi dan non hipertensi ( $p>0,05)$.

Pada pemeriksaan kolesterol total didapat rerata $219,53 \pm 46,13 \mathrm{mg} / \mathrm{dl}$ pada kelompok DM tipe 2 dengan hipertensi dan didapati rerata kadar kolesterol total $176,14 \pm 36,69 \mathrm{mg} / \mathrm{dl}$ pada kelompok non hipertensi. Dijumpai perbedaan bermakna antara kadar kolesterol total pada kelompok DM tipe 2 dengan hipertensi dan kelompok non hipertensi $(\mathrm{p}<0,05)$, sementara pada pemeriksaan kadar trigliserida yang dilakukan pada kedua kelompok 
didapat rerata kadar trigliserida dalam darah adalah $193,28 \pm 140,51 \mathrm{mg} / \mathrm{dl}$ untuk kelompok DM tipe 2 dengan hipertensi dan rerata $149,14 \pm 65,39 \mathrm{mg} /$ dl untuk kelompok non hipertensi. Dalam hal ini dijumpai adanya perbedaan yang bermakna antara kadar trigliserida pada kelompok DM tipe 2 dengan hipertensi dan non hipertensi $(\mathrm{p}<0,05)$.

Pada pemeriksaan HDL didapat rerata $38,83 \pm 10,68 \mathrm{mg} / \mathrm{dl}$ pada kelompok DM tipe 2 dengan hipertensi dan rerata $32,61 \pm 8,87 \mathrm{mg} / \mathrm{dl}$ untuk non hipertensi dan dijumpai perbedaan bermakna antara HDL pada DM tipe 2 dengan hipertensi dan non hipertensi $(\mathrm{p}<0,05)$. Sementara pada pemeriksaan LDL pada kelompok DM tipe 2 dengan hipertensi didapati rerata kadar LDL adalah $151,08 \pm 35,55 \mathrm{mg} / \mathrm{dl}$, lebih tinggi dibandingkan pada kelompok non hipertensi dengan rerata adalah $113,75 \pm 31,12 \mathrm{mg} / \mathrm{dl}$ dan secara statistik dijumpai perbedaan bermakna kadar LDL pada kedua kelompok dengan nilai $\mathrm{p}<0,05$.

\section{PEMBAHASAN}

Aterosklerosis merupakan proses yang bersifat kompleks. Dalam pembentukannya melibatkan disfungsi endotel, gangguan metabolism lipid, stres oksidatif, aktivasi otot polos pembuluh darah, faktor genetik, dan akhir-akhir ini juga diketahui secara luas adanya peranan inflamasi pada setiap tahapan terbentuknya aterosklerosis. Hubungan sindroma metabolik dengan faktor risiko penyakit kardiovaskuler adalah terjadinya proses aterosklerosis yang menggambarkan terjadinya disfungsi endotel. Faktor tekanan darah, obesitas sentral, hiperinsulinemia dan dislipidemia ini diawali dengan keadaan resistensi insulin. Dari beberapa penelitian membuktikan bahwa peningkatan dari kadar LDL Kolesterol dihubungkan dengan peningkatan resiko kejadian penyakit kardiovaskular sesuai dengan studi terdahulu. ${ }^{7}$

Kelompok DM tipe 2 dengan hipertensi dengan karakteristik jenis kelamin paling banyak terdapat pada perempuan. Penyebaran terbanyak pada kelompok usia 51-60 tahun. Sedangkan pada Kelompok DM tipe 2 non hipertensi (kontrol) sebagian besar berjenis kelamin laki-laki. Penyebaran terbanyak juga terjadi pada kelompok usia 51-60 tahun. Pada kedua kelompok ini memperlihatkan ada perbedaan bermakna pada jenis kelamin penderita DM tipe 2 dengan hipertensi dengan penderita non hipertensi $(p<0,05)$.

Studi sebelumnya yang dilakukan Asdie tahun 2005 menyatakan bahwa dari 72 subjek DM tipe 2 ditemukan dengan komorbid hipertensi sebanyak 56 orang dengan karakteristik jenis kelamin paling banyak pada perempuan. Sedangkan pada kelompok DM tipe 2 non hipertensi perbandingan jenis kelamin sama antara laki-laki dan perempuan. Pada kedua kelompok ini memperlihatkan tidak ada perbedaan bermakna pada umur dan IMT penderita DM tipe 2 dengan hipertensi dibandingkan dengan penderita non hipertensi $(p>0,05){ }^{8}$

Berbeda dengan hasil yang didapatkan, pada penelitian ini dimana jenis kelamin laki-laki lebih tinggi dibandingkan wanita pada kelompok hipertensi dengan dislipidemia demikian juga pada kelompok hipertensi non dislipidemia $(p>0,05)$. Hal ini mengindikasikan bahwa jenis kelamin lelaki memiliki andil yang besar terhadap resiko hipertensi dan dislipedemia. Selain itu penelitian ini juga menemukan hubungan yang bermakna antara kadar LDL kolesterol pada DM tipe 2 dengan hipertensi $(\mathrm{p}<0,05)$ dan tidak dijumpai hubungan yang bermakna antara kadar LDL kolesterol dengan kolesterol total, trigliserida, maupun HDL.

Kejadian hipertensi tidak terlepas dari peristiwa aterosklerosis. Mekanisme timbulnya aterosklerosis pada diabetes melitus dan dislipidemia diduga melalui beberapa kemungkinan, yaitu: a. Lipoprotein pengidap diabetes mengalami glikosiliasi (lipoprotein terglikosiliasi) yang bersifat sitotoksik terhadap endotel vasa; b. Lipoprotein (LDL maupun HDL) mengalami oksidasi, sehingga terjadi peninggian lipoprotein peroksida di ruang interstisial atau dinding vasa, dan berinteraksi dengan otot polos dan makrofag, sehingga terjadi akumulasi lemak; dan c. Katabolisme LDL terhambat karena adanya residulisin menyebabkan LDL mengalami karbamalasi. ${ }^{9}$ Ketiga proses yang terjadi, glikosilasi, oksidasi, dan karbamalasi LDL, akan menghambat ambilan LDL oleh scavenger cells dalam tubuh. ${ }^{10}$ Selain itu, LDL yang terglikosilasi bersifat imunogen dan dapat bereaksi dengan antibodi yang terbentuk dan kompleks antigen-antibodi yang terjadi akan merusak endotel vasa. ${ }^{11}$ VLDL ikut berperan dalam proses aterogenesis dengan mengangkut lipid dari hepar ke dinding arteri. Sumbatan aterosklerosis ini merupakan penyebab terjadinya peningkatan systemic vascular resistance yang berhubungan dengan peningkatan tekanan darah (Hipertensi).

\section{SIMPULAN}

Pada penelitian ini ditemukan hubungan yang positif antara meningkatnya kadar kolesterol total, trigliserida, HDL dan LDL dengan hipertensi pada populasi DM tipe 2 secara bermakna. Akan tetapi, studi lebih lanjut dengan ukuran sampel lebih besar beserta jenis penelitian yang bersifat prospektif diperlukan untuk menentukan hubungan kausal longitudinal. 


\section{ETIKA PENELITIAN}

Penelitian ini telah mendapatkan persetujuan etik dari komisi etik Fakultas Kedokteran Universitas Sumatera Utara, Medan, Indonesia sebelum dilakukan.

\section{KONFLIK KEPENTINGAN}

Tidak terdapat konflik kepentingan dalam penulisan publikasi ini.

\section{PENDANAAN}

Penulis bertanggung jawab terhadap secara mandiri dalam pendanaan penelitian ini.

\section{KONTRIBUSI PENULIS}

Seluruh penulis memiliki kontribusi yang sama dalam penyusunan laporan hasil penelitian pada publikasi ini.

\section{DAFTAR PUSTAKA}

1. Malloy Mary J, Kane John P. Agen yang digunakan dalam hiperlipidemia. Dalam : Katzung Bertram. Farmakologi dasar dan klinik. Edisi 8. Jakarta : Salemba Medika. 2002; 421-2.

2. Bakri Syakib, What have we learn about ARB, especially for diabetes hypertension. Dalam Kongres nasional X pernefri, Annual meeting. 2007: 97.
3. Boestan Iwan N, Baedowi Andrianto. The role of interventional cardiology in coronary artery disease with diabetes. Dalam: Adi Soebagijo, Nasronudin, Sutjahjo Ari, et al. Naskah lengkap pendidikan kedokteran berkelanjutan XXII. Surabaya: Bagian Ilmu Penyakit Dalam FK-UNAIR, 2007:557.

4. Waspadji Sarwono. Penyulit Kronik Dan Pencegahannya. Dalam: Soegondo Sidartawan, Soewondo Pradana, Subekti Imam. Penatalaksanaan Diabetes Melitus Terpadu. Edisi ke-6. Jakarta : FK UI. 2007.

5. Yates A. John, DeFronzo Ralph A. Kelainan metabolisme. Dalam: Stein Jay H. Panduan klinik ilmu penyakit dalam. Edisi ketiga. Jakarta: EGC, 2001: 660.

6. Tjokroprawiro A, Hendromartono, Piliang S. Simposium Dimensi Baru Penatalaksanaan Diabetes Melitus Tidak Tergantung Insulin 1996; 1-3.

7. Ference BA, Ginsberg HN, Graham I et al. Low-density lipoproteins cause atherosclerotic cardiovascular disease. 1. Evidence from genetic, epidemiologic, and clinical studies. A consensus statement from the European Atherosclerosis Society Consensus Panel. Eur Heart J. 2017; 38(32): 2459-2472.

8. Asdie AH. Hubungan LDL dengan Hipertensi Pada Populasi DM Tipe 2. The International Journal of Internal Medicine. 2015; 1-7.

9. Dzau VJ. Atherosclerosis and hypertension: mechanisms and interrelationships. J Cardiovasc Pharmacol. 1990; Suppl 5:S59-64.

10. Lastra G, Syed S, Kurukulasuriya LR, et al. Type 2 diabetes mellitus and hypertension: An update. Endocrinol Metab Clin North Am. 2014 Mar; 43(1): 103-122.

11. Sarkar D, Latif SA, Uddin MM et al. Studies on serum lipid profile in hypertensive patient. Mymensingh Med J. 2007;16(1):70-6.

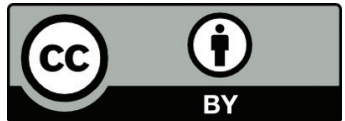

This work is licensed under a Creative Commons Attribution 